\title{
Reasonable Outcome of Avulsed Permanent Upper Incisor after Seven Years Follow-Up Period: a Case Report
}

\author{
Egle Bendoraitiene ${ }^{1}$, Sandra Zemgulyte ${ }^{1}$, Marija Borisovaite ${ }^{1}$ \\ ${ }^{1}$ Clinic for Preventive and Pediatric Dentistry, Lithuanian University of Health Sciences, Kaunas, Lithuania. \\ Corresponding Author: \\ Marija Borisovaite \\ Medical Academy \\ Lithuanian University of Health Sciences \\ J. Luksos-Daumanto 6, 50106, Kaunas \\ Lithuania \\ Phone: +37065050213 \\ E-mail: marija.borisovaite@gmail.com
}

\begin{abstract}
Background: Avulsion of the permanent teeth is one of the most serious oral health problems among active children and adolescents. Traumatized patients require immediate and correct treatment in order to restore damaged structures and function that have major impact on daily patient's life. As a result, proper guidelines and fast treatment methods are necessary. This case report discusses treatment of maxillary right central incisor with an open apex that had been avulsed and replanted. We review applied treatment procedures to manage dental avulsion and restore function and aesthetics.

Methods: A 10-year-old male presented with avulsion of his maxillary right central incisor as a result of unintentional playground injury. The tooth had been stored dry before the patient received immediate care. The avulsed tooth was reimplanted and splinted. The applied treatment procedures include endodontic and restorative treatment as well as careful follow-up visits. Results: The patient underwent endodontic therapy of his maxillary right central incisor with calcium hydroxide as an intracanal medicament in apexification technique and the closure of apex was achieved. Canal was obturated and the tooth was restored with composite resin. Clinical and radiographic imaging follow-up showed endodontic success with closed apex. However, severe infra-position of maxillary right central incisor developed due to ankylosis.

Conclusions: Ankylosis due to tooth avulsion is a common complication of reimplanted permanent incisors and must be taken into consideration. While addressing ankylosis and its results is supported by little evidence, every case must be diagnosed correctly and treated according to its negative outcomes.
\end{abstract}

Keywords: ankylosis of teeth; tooth avulsion; tooth reimplantation.

Accepted for publication: 20 December 2017

To cite this article:

Bendoraitiene E, Zemgulyte S, Borisovaite M.

Reasonable Outcome of Avulsed Permanent Upper Incisor after Seven Years Follow-Up Period: a Case Report

J Oral Maxillofac Res 2017;8(4):e6

URL: http://www.ejomr.org/JOMR/archives/2017/4/e6/v8n4e6.pdf

doi: $10.5037 /$ jomr.2017.8406 


\section{INTRODUCTION}

Tooth avulsion in permanent dentition ranges from 0.5 to $3 \%$ of all dental injuries and is a relatively infrequent type of dental traumas [1]. The peak of dental injuries occurs between the ages 8 and 11 years consequently, the growth spurt during this period might influence the development of complications $[\underline{2}, \underline{3}]$. The traumatic extraction of the tooth from its socket causes multiple injuries of the surrounding structures as periodontal ligaments, neurovascular bundles, root cementum, alveolar bone and gingiva [4]. Immediately, after avulsion, both pulpal and periodontal ligament (PDL) cells begin to suffer ischemic injury, which can be deteriorated by drying, bacteria and chemical irritants. These negative factors cause the loss of vitality to these PDL cells and dehydration to the pulpal cells, which are invaluable for tooth survival $[1,5]$. Treatment of tooth avulsion is often complicated and prognosis can be poor regarding to the damage severity of both tooth and supporting structures; the other factors such as a status of avulsed tooth, root maturation level, current extraoral period and storage conditions of avulsed tooth before the reimplantation, a chosen treatment method, type and duration of splinting play important role as well $[\underline{6}, 7]$. Complications of tooth avulsion can occur after several months or even years and the most common are pulp necrosis, pulp canal obliteration, inflammatory root resorption and ankylosis $[\underline{8}, \underline{\underline{ }}]$. Therefore, the treatment of avulsed teeth is very difficult and further complications are often []․ Nevertheless, maintaining the tooth and surrounding bone for a few years can be considered a successful treatment method for growing patient [10].

Dentoalveolar ankylosis is a frequent complication after reimplantation of avulsed teeth. Considering results of previous studies, prevalence of the ankylosis ranges between $57 \%$ and $80 \%$ in avulsed and replanted teeth [11]. Ankylosis is described as a solid fixation of tooth resulting from fusion of the cementum to the alveolar bone, with obliteration of the periodontal ligament $[12,13]$. It is a serious condition since the remodelling process of the alveolar bone and adjacent teeth are affected after trauma [14]. Although ankylosis in adults can be successfully managed applying prosthodontic therapy or implantation, when growth process is not completed, the ankylosed tooth becomes a challenge for both patient and dentist [13-15]. When avulsion occurs during pre-adolescence or adolescence periods, ankylosis interferes with dentoalveolar development, which often leads to continuing root replacement resorption, tooth infra-position and disturbed alveolar ridge development $[9,12,15]$. In some cases, when the affected tooth is restricted to respond of the natural eruption, results of developed ankylosis often varies from an infra-position of the tooth to more severe aesthetic deficits such as ridge deformity and tilted adjacent teeth [15]. In growing patients, especially during period of growth spurts, these changes can progress so far, that effective orthodontic or prosthetic therapy becomes difficult. In these cases, an alternative therapy known as decoronation technique can be applied to achieve satisfactory outcome [16] When the prosthodontic treatment can improve the situation, but not really correct the incorrect position of tooth, orthodontic therapy can be included as well. A newly developed procedure called orthodontic bone stretching has been effective in relocating ankylosed teeth. This procedure can be a potential solution before tooth extraction [17].

The present study aims to report a case of treatment of maxillary right central incisor with an open apex that had been avulsed and replanted. The aim of the treatment was to re-establish normal tooth position, colour and gingival contour and to maintain an adequate tooth function, for instance, ability to bite without pain. Despite the developed complications such as pulp necrosis, infection-related root resorption and infra-occlusion, a long-term survival of natural tooth, maintaining an integrity and physiological, emotional and social well-being of patient was achieved.

\section{CASE DESCRIPTION AND RESULTS}

A 10-year-old patient reported to Kaunas Clinics Department of Emergency Medicine due to occurred dental trauma injury on February 6, 2010. The trauma happened in a playground when a friend accidentally threw a brick, which avulsed the tooth. Patient arrived to the Department of Emergency Medicine within an hour. The avulsion of tooth \#11 was diagnosed as well as wounded upper lip. Avulsed tooth was stored in dry condition and did not have a contact with soil. Patient was in good general health and no contraindications for reimplantation were reported. After administration of local anaesthetic (Lidocaine $2 \%-1.5 \mathrm{ml}$ ), the tooth was reimplanted and fixed with rigid metal splint, by finger pressure. Displaced tooth was splinted using an Erich-arch bar (rigid splinting) because bonding technique was not available in hospital emergency room. The wound of upper lip was closed with sutures. Two days later (August 2, 2010) the patient was consulted due to further treatment in the Clinic for 
Preventive and Paediatric Dentistry. The clinical examination revealed the following symptoms such as: mildly swollen sutured upper lip which was painful during palpation. Teeth \#12, \#11 and \#21 were splinted by rigid metal splint, surfaces of teeth were covered with soft plaque (patient did not brush his teeth after trauma). The control periapical radiographic image showed open apex and wide pulp canal (Figure 1).

The following oral hygiene and dietary instructions according to the dental trauma guidelines were given: soft food diet for up to 2 weeks, teeth brushing with a soft or ultra-soft toothbrush after each meal, mouth rinsing with chlorhexidine $(0,1 \%)$ twice a day for 1 week. Systemic antibiotics (Amoxicillin, 500 mg orally 2 times a day for 7 days) were prescribed as well. In addition, it was recommended to avoid participation in contact sports [1].

After two weeks a control check-up revealed no complaints, mobility of tooth \#11 was physiological. Patient was referred to oral surgeon for splint removal, consequently the results of cold pulp test ("Cold Spray", Polydent, Germany) showed that boy felt a cold similarly with all examined teeth.

After next two weeks, patient came for follow-up visit and did not have any complaints. No clinical and radiographic pathological changes such as mild external resorption were observed (Figure 2). The next follow-up visit was scheduled after one month, but patient referred to clinic only after two months. He did

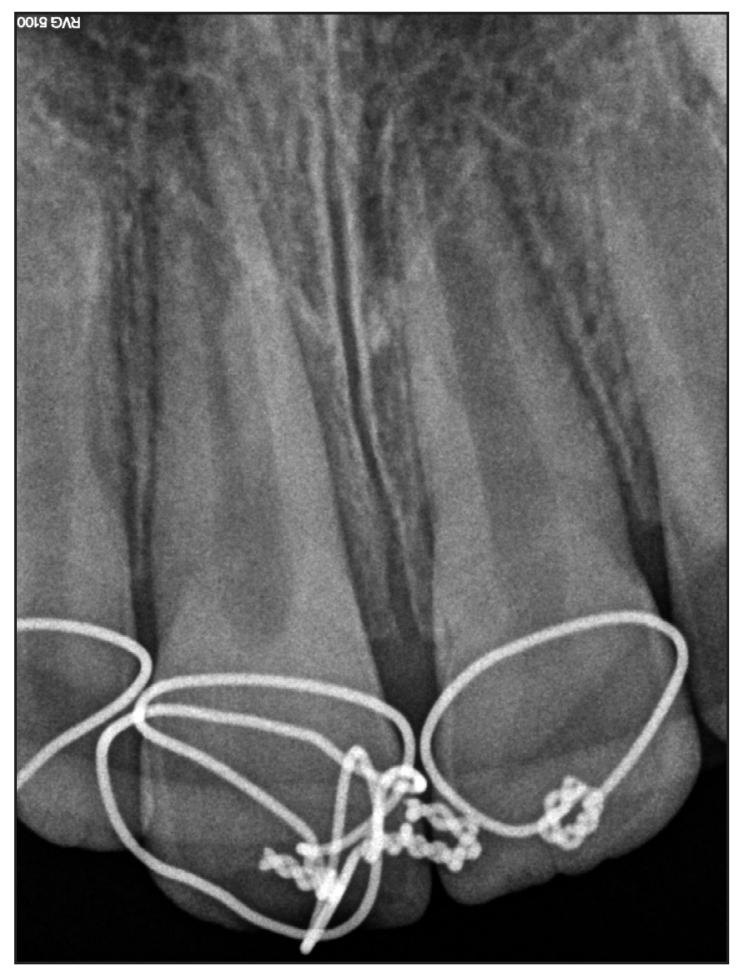

Figure 1. Two days after avulsion of tooth \#11. Periapical radiograph showing splinted teeth $\# 12$, \#11 and \#21, wide apexes of teeth \#11 and \#21 are observed. not have any complaints, whereas clinical examination revealed sensitivity of tooth \#11 for both vertical and horizontal percussion. Standard radiographic examination showed severe external inflammatory resorption at the lateral root surfaces (Figure 3).

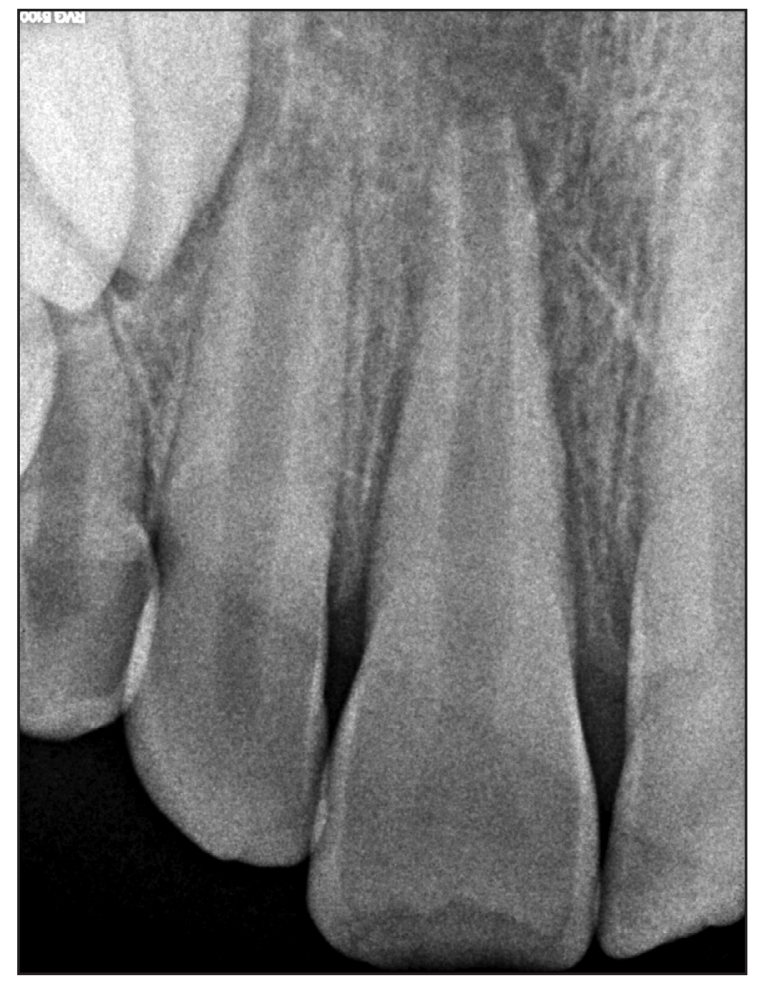

Figure 2. Two weeks after trauma. Dental radiograph showing mild external resorption and periapical lesion of tooth \#11.

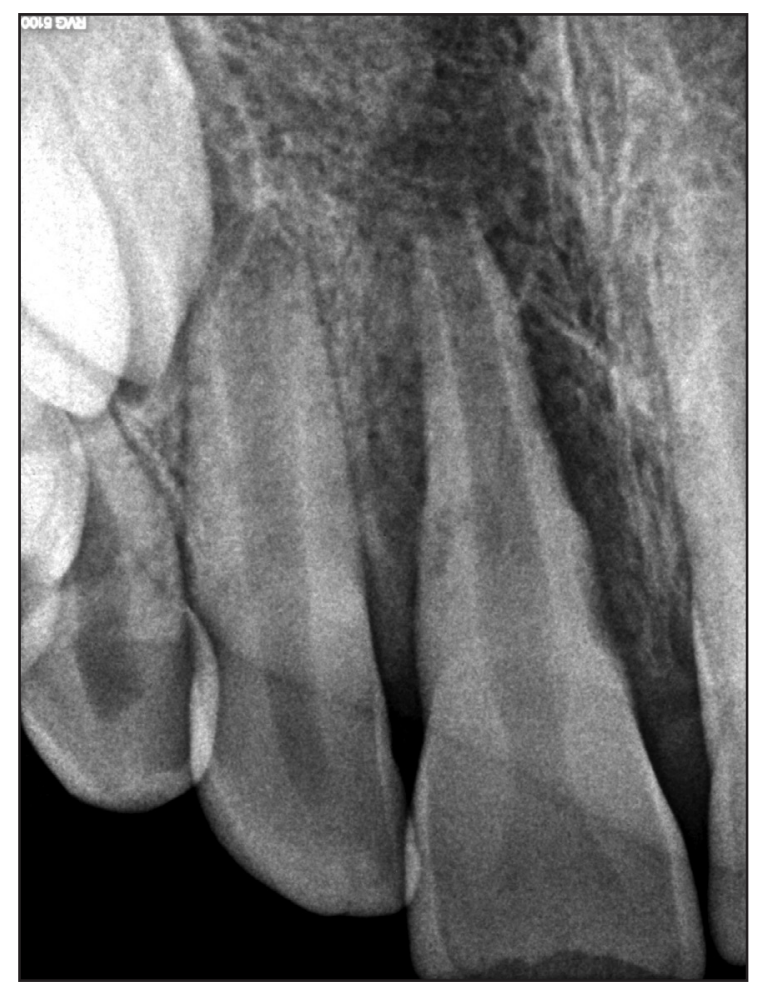

Figure 3. Three motnhs after avulsion. Dental radiograph showing severe external resorption and periapical lesion of tooth \#11. 


\section{Treatment}

The access cavity was prepared using a diamond round bur with irrigation. Necrotic pulp was extirpated from root canal. Working length was determined with an apex locator with the use of \#60 K-file (Maillefer Instruments SA, Ballaiques, Switzerland). The decontamination protocol included slow and careful irrigation with $2.5 \%$ Sodium hypochlorite $(\mathrm{NaOCl})$ solution. The root canal was dried with large paper points and then filled

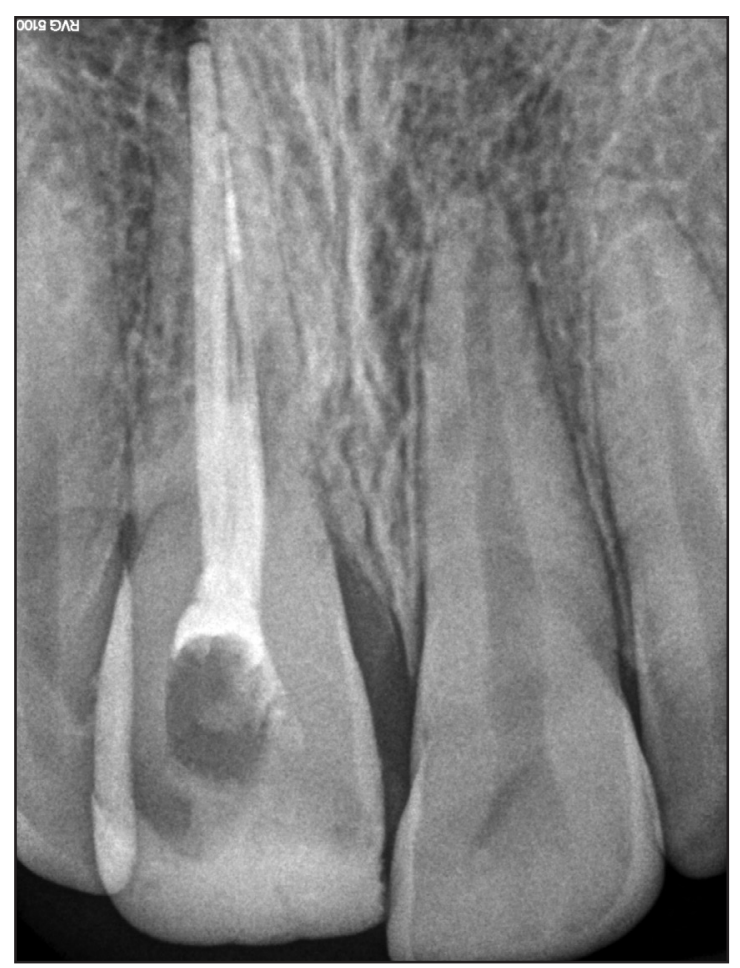

Figure 4. At 7-year follow-up period. Dental radiograph showing no resorption; infra-occlusal position of tooth \#11 is observed. with calcium hydroxide as an intracanal medication (Calcipast, Cerkamed) with lentulo spiral (Dentsply Maillefer, Tusla, OK, USA). The cavity was sealed with IRM (Dentsply, Konstanz, Germany). The procedure was repeated every 2 weeks for over 2 months, later, once in 2 months till the obturation. Apexofication method using calcium hydroxide was applied in order to formate apical barrier relating to its successful results and wide acceptance [19]. All clinical symptoms: mobility, sensitivity to percussion, swelling of surrounding tissues, were relieved.

The root canal was obturated with $\mathrm{ZnO}$ eugenol based sealer (Caryosan, Spofa Denta) and guttapercha points (MGP \#80). The cavity of tooth was filled with "Adhesor Fine" (Spofa Dental, Jicín, Czech Republic) liner and composite filling "Gradia" (shades A2, A3) (GC; Tokyo, Japan).

During regular follow-up visit after three years, the gingival pocket and "shortened" crown of tooth \#11 were diagnosed. Regarding to periodontist recommendations, professional oral hygiene procedure was accomplished. One month later, an improvement of gingival status was observed, mild bleeding during probing was detected in the distal marginal area of tooth \#11. The shortened crown was restored with composite filling "Charisma" (shade A2 and OL) (Heraeus-Kulzer).

Clinical findings of last (six years after trauma) checkup were infra-occlusal position of tooth \#11, mild discoloration of crown, no mobility, no sensitivity to percussion and palpation. Ankylosis of tooth was observed in both panoramic and control periapical radiographs (Figures 4 - 6).

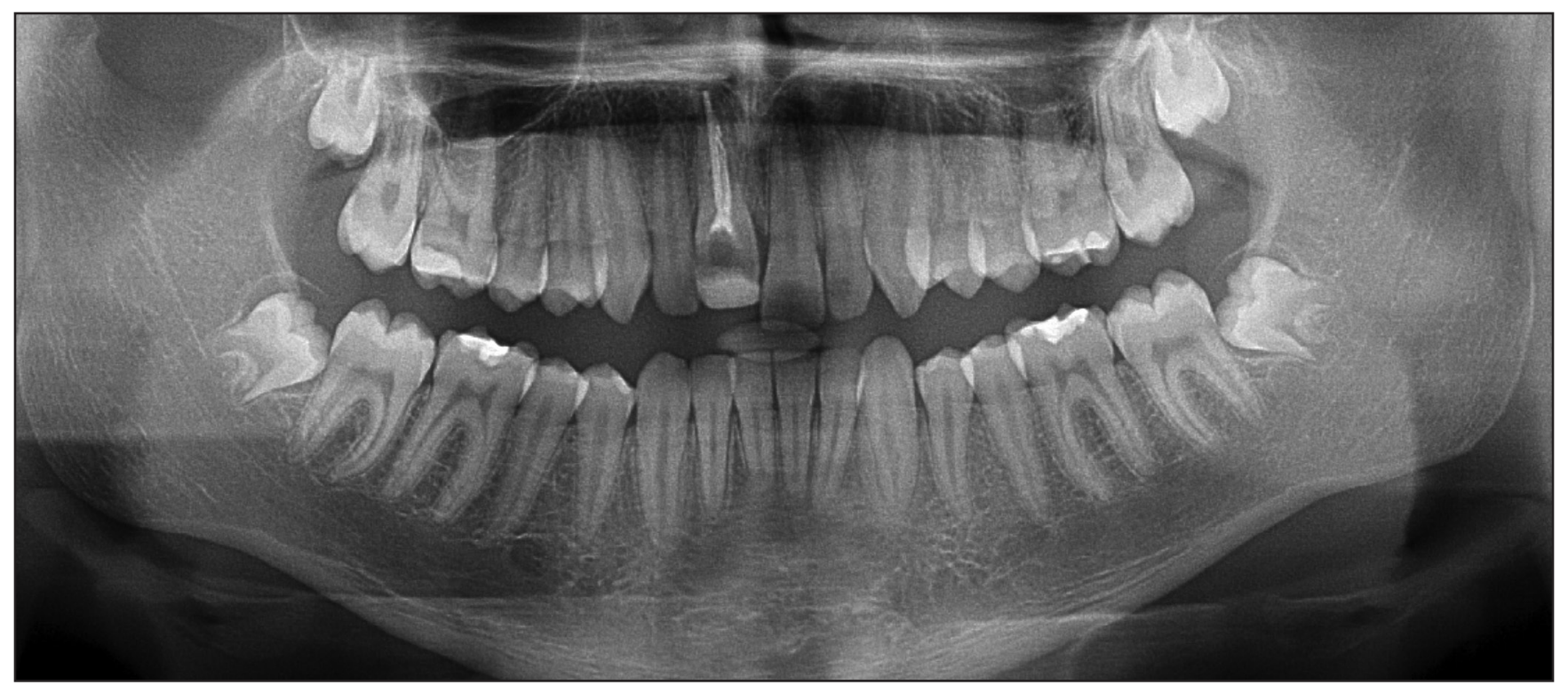

Figure 5. Seven-year follow-up of replanted tooth. Panoramic radiograph showing infra-occlusal position of tooth \#11. 


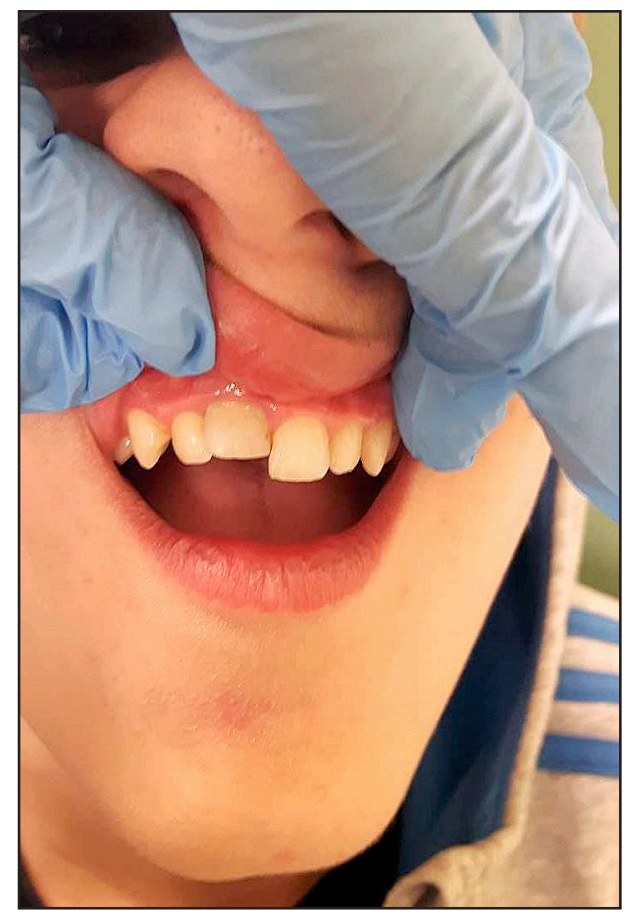

Figure 6. Clinical view showing infra-occlusal position and mild discoloration of tooth \#11, 7 years after trauma.

\section{DISCUSSION}

Traumatized tooth needs to be reimplanted immediately after avulsion. Even after immediate reimplantation, only $73 \%$ of cases have normal desmodontal tissue after healing is complete due to extraoral dry time of maximum five minutes. Moreover, in cases of 10 minutes extraoral dry time, the optimal healing is observed in only $50 \%$ [20].

Long-term success of treatment is directly related to extraoral period of avulsed tooth and the best results are achieved when this period is less than 20 minutes [7]. When it is not possible to reimplant the tooth immediately after the accident, the tooth must be kept in physiological storage media such as Hank's Balanced Salt Solution (HBSS), saliva, saline and milk $[1,7,21]$. After reimplantation, it is recommended to splint the tooth using a semi-rigid splint for $7-10$ days. In some cases, depending on clinical situation, the tooth should be splinted for a longer period. Rigid immobilization of avulsed tooth is contraindicated [7]. In this case several factors such as long extraoral period, dry storage of avulsed tooth and rigid surgical splint worsened the prognosis.

The endodontic treatment of a tooth with developed roots should be performed in order to prevent possible complications. While in immature teeth, when the apex is open, revascularization of the pulp may occur, but follow-up visits should be scheduled monthly during the first three months [22] .
In the final analysis, pulp, periodontal tissues and alveolar bone are involved in healing process after reimplantation of an avulsed tooth. Depending on various factors, the following healing modalities can occur: pulp survival, pulp necrosis or pulp obliteration [23]. The most common stimulation factor for root resorption is necrotic and infected pulp. Survival of the tooth directly depends on the stage of root development at the time of reimplantation. According to the studies comparing the survival rates of teeth with open and closed apices after avulsion injury, immature permanent teeth with open apices indicate lower survival in comparison to teeth with closed apices [24]. In this clinical case, the condition could be deteriorated because the patient did not come for follow-up visits and arrived only when clinical symptoms were well-defined. In cases when clinical and radiological inflammatory symptoms are present, the endodontic therapy should be performed and formation of apex barrier should be accomplished with calcium hydroxide, MTA or other materials $[\underline{22}, \underline{25}]$. In this case, endodontic treatment with calcium hydroxide prevented from resorption process and root canal was obturated with gutta-percha.

Not only inflammatory resorption can develop, but also surface resorption and replacement resorption (ankylosis-related root resorption) can occur in trauma cases as well. Replacement resorption develops after death of viable periodontal ligament cells due to drying or compression of ligament cells [26]. Significantly, more teeth with splinting periods of $>10$ days presented with replacement resorption compared to the teeth with splinting periods of maximum 10 days [23].

In our case many clinical factors, such as extraalveolar dry period of 60 minutes, immature tooth with open apices, young patient's age, bad oral hygiene, rigid metal splint for two days after avulsion, played a significant role in prognosis of long-term outcome and showed a high probability of complications. Nevertheless, the natural tooth was saved and provided moderate aesthetic results. In addition, it functioned as a space, bone and gingivae maintainer, satisfying the aesthetic needs of the patient and performing physiological functions until implantation procedures are needed or will be possible.

\section{CONCLUSIONS}

Ankylosis due to avulsion is a common complication of reimplanted permanent incisors and must be taken into consideration. Despite of age, ankylosed incisors 
are frequently associated with infra-position and lack of physiological mobility. Whereas addressing ankylosis and its effects are supported by little evidence, every case must be diagnosed correctly and treated according to its negative consequences.

\section{ACKNOWLEDGMENTS AND DISCLOSURE STATEMENTS}

All the authors declare there are no competing interests related to this publication.

\section{REFERENCES}

1. Andersson L, Andreasen JO, Day P, Heithersay G, Trope M, DiAngelis AJ, Kenny DJ, Sigurdsson A, Bourguignon C, Flores MT, Hicks ML, Lenzi AR, Malmgren B, Moule AJ, Tsukiboshi M. Guidelines for the Management of Traumatic Dental Injuries: 2. Avulsion of Permanent Teeth. Pediatr Dent. 2017 Sep 15;39(6):412-419. [Medline: 29179383] [doi: 10.1111/j.1600-9657.2012.01125.x]

2. Petersson EE, Andersson L, Sörensen S. Traumatic oral vs non-oral injuries. Swed Dent J. 1997;21(1-2):55-68. [Medline: 9178450 ]

3. Al-Obaida M. Knowledge and management of traumatic dental injuries in a group of Saudi primary schools teachers. Dent Traumatol. 2010 Aug;26(4):338-41. [Medline: 20662887] [doi: 10.1111/j.1600-9657.2010.00894.x]

4. Tezel H, Atalayin C, Kayrak G. Replantation after traumatic avulsion. Eur J Dent. 2013 Apr;7(2):229-32. [Medline: 24883032] [PMC free article: 4023196] [doi: 10.4103/1305-7456.110192]

5. Sigalas E, Regan JD, Kramer PR, Witherspoon DE, Opperman LA. Survival of human periodontal ligament cells in media proposed for transport of avulsed teeth. Dent Traumatol. 2004 Feb;20(1):21-8. [Medline: 14998411] [doi: 10.1111/j.1600-4469.2004.00219.x]

6. Karayilmaz H, Kirzioglu Z, Erken Gungor O. Aetiology, treatment patterns and long-term outcomes of tooth avulsion in children and adolescents. Pak J Med Sci. 2013 Apr;29(2):464-8. [Medline: 24353557] [PMC free article: 3809259] [doi: 10.12669/pjms.292.3283]

7. Ram D, Cohenca N. Therapeutic protocols for avulsed permanent teeth: review and clinical update. Pediatr Dent. 2004 May-Jun;26(3):251-5. [Medline: 15185807]

8. Soares AJ, Souza GA, Pereira AC, Vargas-Neto J, Zaia AA, Silva EJ. Frequency of root resorption following trauma to permanent teeth. J Oral Sci. 2015 Jun;57(2):73-8. [Medline: 26062854] [doi: 10.2334/josnusd.57.73]

9. Finucane D, Kinirons MJ. External inflammatory and replacement resorption of luxated, and avulsed replanted permanent incisors: a review and case presentation. Dent Traumatol. 2003 Jun;19(3):170-4. [Medline: 12752540] [doi: $10.1034 / j .1600-9657.2003 .00154 . x$ ]

10. Trope M. Avulsion of permanent teeth: theory to practice. Dent Traumatol. 2011 Aug;27(4):281-94. [Medline: 21635689] [doi: 10.1111/j.1600-9657.2011.01003.x]

11. Zaleckiene V, Peciuliene V, Brukiene V, Drukteinis S. Traumatic dental injuries: etiology, prevalence and possible outcomes. Stomatologija. 2014;16(1):7-14. [Medline: 24824054]

12. Zhu W, Zhang Q, Zhang Y, Cen L, Wang J. PDL regeneration via cell homing in delayed replantation of avulsed teeth. J Transl Med. 2015 Nov 14;13:357. [Medline: 26572489] [PMC free article: 4647325] [doi: 10.1186/s12967-015-0719-2]

13. Mohadeb JV, Somar M, He H. Effectiveness of decoronation technique in the treatment of ankylosis: A systematic review. Dent Traumatol. 2016 Aug;32(4):255-63. [Medline: 26663218] [doi: 10.1111/edt.12247]

14. Andersson L, Blomlöf L, Lindskog S, Feiglin B, Hammarström L. Tooth ankylosis. Clinical, radiographic and histological assessments. Int J Oral Surg. 1984 Oct;13(5):423-31. [Medline: 6438004] [doi: 10.1016/S0300-9785(84)80069-1]

15. Campbell KM, Casas MJ, Kenny DJ. Ankylosis of traumatized permanent incisors: pathogenesis and current approaches to diagnosis and management. Tex Dent J. 2006 Jul;123(7):596-601. [Medline: 16903432]

16. Malmgren B. Decoronation: how, why, and when? J Calif Dent Assoc. 2000 Nov;28(11):846-54. [Medline: 11811233]

17. Bousquet $P$, Renaud M, Artz C. Relocation of ankylosed teeth and implants using orthodontic bone stretching technique: a clinical study and preliminary results. Clin Oral Impl Res. 2015 Sep 24;26(Suppl 12):185. [doi: doi: 10.1111/clr.178_12679]

18. American Academy on Pediatric Dentistry Council on Clinical Affairs. Guideline on management of acute dental trauma. Pediatr Dent. 2008-2009;30(7 Suppl):175-83. [Medline: 19216418]

19. Rafter M. Apexification: a review. Dent Traumatol. 2005 Feb;21(1):1-8. [Medline: 15660748] [doi: 10.1111/j.1600-9657.2004.00284.x]

20. Brüllmann D, Schulze RK, d' Hoedt B. The Treatment of Anterior Dental Trauma. Deutsches Ärzteblatt International. 2011 Dec 30;108(34-35):565-70. [PMC free article: 3167059] [doi:10.3238/arztebl.2011.0565]

21. Poi WR, Sonoda CK, Martins CM, Melo ME, Pellizzer EP, de Mendonça MR, Panzarini SR. Storage media for avulsed teeth: a literature review. Braz Dent J. 2013 Sep-Oct;24(5):437-45. [Medline: 24474282] [doi: 10.1590/0103-6440201302297]

22. Moule AJ, Moule CA. The endodontic management of traumatized permanent anterior teeth: a review. Aust Dent J. 2007 Mar;52(1 Suppl):S122-37. [Medline: 17546867] [doi: 10.1111/j.1834-7819.2007.tb00520.x] 
23. Chappuis V, von Arx T. Replantation of 45 avulsed permanent teeth: a 1-year follow-up study. Dent Traumatol. 2005 Oct;21(5):289-96. [Medline: 16149925] [doi: 10.1111/j.1600-9657.2005.00330.x]

24. Petrovic B, Marković D, Peric T, Blagojevic D. Factors related to treatment and outcomes of avulsed teeth. Dent Traumatol. 2010 Feb;26(1):52-9. [Medline: 19919541] [doi: 10.1111/j.1600-9657.2009.00836.x]

25. Guideline on Pulp Therapy for Primary and Immature Permanent Teeth. Pediatr Dent. 2016 Oct;38(6):280-288. [Medline: 27931467]

26. Heithersay GS. Management of tooth resorption. Aust Dent J. 2007 Mar;52(1 Suppl):S105-21. [Medline: 17546866] [doi: 10.1111/j.1834-7819.2007.tb00519.x]

\section{To cite this article:}

Bendoraitiene E, Zemgulyte S, Borisovaite M.

Reasonable Outcome of Avulsed Permanent Upper Incisor after Seven Years Follow-Up Period: a Case Report

J Oral Maxillofac Res 2017;8(4):e6

URL: http://www.ejomr.org/JOMR/archives/2017/4/e6/v8n4e6.pdf

doi: $10.5037 /$ jomr.2017.8406

Copyright $(C$ Bendoraitiene E, Zemgulyte S, Borisovaite M. Published in the JOURNAL OF ORAL \& MAXILLOFACIAL RESEARCH (http://www.ejomr.org), 31 December 2017.

This is an open-access article, first published in the JOURNAL OF ORAL \& MAXILLOFACIAL RESEARCH, distributed under the terms of the Creative Commons Attribution-Noncommercial-No Derivative Works 3.0 Unported License, which permits unrestricted non-commercial use, distribution, and reproduction in any medium, provided the original work and is properly cited. The copyright, license information and link to the original publication on (http://www.ejomr.org) must be included. 